\title{
Departmental Institutions and Decentralised Cooperation in Boyacá
}

\author{
Instituciones departamentales y cooperación \\ decentralizada en Boyacá
}

José L. Niño Amezquita ${ }^{1}$

Para citar este artículo, utilice el nombre completo así:

Niño, J. L. (2015). Departmental Institutions and Decentralised Cooperation in Boyacá. Perspectiva Geográfica, 20(1), 37-70.

\begin{abstract}
The Colombian reality shows how subnational entities have been affected by a process of recentralisation since the beginning of the XXI century, and the weakening of intermediate entities in the decentralisation of the last century. However, these entities are seen as the linkage for territorial internationalization, an empty space that few municipalities have adopted and within which departments have hardly acted. Boyacá, a territory in the middle of the Andes, faces challenges that, until now, it has been unable to answer in the right way. The current document is based on primary data which analyses the cooperation from the department as well as the municipalities. Therefore, the internal dynamics and realities suggest that the solution may lie on the integration that Boyacá and its municipalities might have with inter-subnational peers. However, this is still a long path to walk for the Colombian territorial entities, especially in the Department of Boyacá.
\end{abstract}

1 Doctor en Instituciones, Administraciones y Políticas Regionales del Centro de Investigación Regional Lombardo: Eupolis (consorcio de las Universidades de Pavía, Milán, Católica y el Politécnico de Milán). Economista de la Universidad de Los Andes con maestrías en Geografía Humana del Instituto de Geografía de París y Gobernanza y Políticas de Desarrollo de la Escuela de Altos Estudios Internacionales y Políticos. jnasc82@yahoo.com 
Keywords: Boyacá, descentralized cooperation, internationalization of territories, intersubnational relations, multilevel governance, paradiplomacy, territorial development.

\section{Resumen}

En Colombia, las entidades sub-nacionales se vieron afectadas por la recentralización desde comienzos del siglo XXI y con el debilitamiento de las entidades intermedias durante la descentralización del siglo pasado. Sin embargo, estas entidades se observan como el articulador de la internacionalización territorial, espacio vacío que pocas municipalidades han adoptado y donde los departamentos han tenido un nulo accionar. Boyacá, territorio inmerso en los andes colombianos, enfrenta retos que hasta hoy no ha afrontado correctamente. El presente documento, se basa en información primaria que contribuye al análisis departamental y municipal de cooperación. Por ello, las dinámicas y realidades internas; sugieren que la solución estaría en la integración que Boyacá, y sus municipalidades, pueda tener con pares inter-subnacionales. Sin embargo, este es un largo camino que falta por caminar para las entidades territoriales colombianas, especialmente del departamento de Boyacá.

Palabras clave: Boyacá, cooperación descentralizada, internacionalización de territorios, relaciones intersubnacionales, gobernanza multinivel, paradiplomacia, desarrollo territorial. 


\section{Rationale}

The problems of territorial organisation have led to a new topic of study, offering a tool for any kind of development policy applied in the southern countries. As territorial internationalisation and decentralised cooperation take on more importance, Colombia is not exempt from these processes. However, up until now, studies and practices have focused on well-known cities and regions, mainly on Bogota, Medellin and its surroundings. This has resulted in a widening of the gap between territories, leaving other zones lagging and without political options or any form of theoretical research.

This is the case in the department of Boyacá, which has had to live with and depend upon the country's large economic centres and national redistribution policies. After the implementation of decentralising policies and the distribution of functions, the department found it difficult to take over responsibilities like relationships with external actors. The situation was now much more complex, due to the redistribution of financial resources in favour of municipalities. Within the context of breaking down of national borders, strengthening of supranational blocs and the influence of multilateral actors in southern countries, this text aims to revalue how Boyacá's government and its institutions play the role of coordinator and bridge for these new public policies.

To approach this issue, the current paper tries to understand the municipal perspective, its departmental aggregate of decentralised cooperation, and the institutional action of Boyacá House; searching to develop the Department as well as its territories within. To analyse this behaviour the research uses primary data, collected with a survey made by the author to the local mayor or the municipal planning secretary. The survey is based primarily on closed questions, and two open questions that approximate the perceptions of each participant. The survey was carried out without prior conceptual explanation, avoiding a conceptual bias and allowing the concept definition be based on the realities that each territorial leader lives. Later, because the data is based on closed forms, it is shown on the document with maps, 
showing if there is any centralperiphery behaviour or any shared provincial actions.

In addition, this article contextualises the Colombian reality and the impact that territorial legislation, coupled with policies aimed towards institutional strengthening, has had on new relations between territories and international actors. The first part tries as well to understand the National perspective build since the departmental reality. Then, the case of Boyacá and its municipalities will be presented. The study will aim to explain how, under the framework set out in the previous section and given the scarce municipal capacities, the department emerges as a central figure in the use of new decentralised cooperation and internationalisation tools, impacting in a real way its territory and population.

\section{Colombian Instability and fragmentation}

Colombia has always been characterised by its fragmented territory, which as well as providing for a diverse cultural make-up, also brings with it problems. Over the years, governments have made the integration of the national territory one of their main priorities, but none have been able to achieve it. What follows is an explanation of the difficulties faced in the construction of the Colombian Nation from its independence in the early 19 th century. The second part of this section will focus on the internationalisation of Colombian departments and the existing subnational units. It is here that one can observe the difficulties it has experienced in the process. This is a result of historic (the conflict) and geographic (the mountains) dynamics that each of the departments has to contend with, establishing relationships outside the national borders becomes more complex, given that they do not even have strong links with the nation or with national peers.

\subsection{The Colombian territorial reality}

Colombia's territory has undergone huge changes over the course of the two centuries following independence, which in part led to the 1991 constitution, a result of Colombia's numerous peace processes. The new millennium marked a restructuring of the central and peripheral perspectives, resulting in a restructuring of 
powers, a process still under construction. Now a historic viewpoint of Colombian territories will be presented. In order to do this, three time periods will be considered: the instability of the 19th century, the strengthening of the unitary state which is later put in doubt, and the construction of a social state that came with the 1991 constitution.

In the second decade of the 19th century, Colombia emerged as an extensive territory which occupied a large part of northern South America. From the creation of Gran Colombia in the post-independence period, the discussion between unitary or federal state would frame 60 years of constitutional instability, which first began when Socorro's 1810 constitution was not adopted (Velandia, 1971). After the disintegration of Gran Colombia in 1831 and the creation of a less extensive national territory, the opportunity to impose a central model emerged. As with so many others, this would be based on the French system. However, with the passing of time and the constant changing of the ruling party, the federal system became the favoured option for liberals, who saw this system of government as the most viable option in the face of the existing territorial fragmentation. The result was, as Planas explains (1997), six constitutions in less than six decades (1832, 1843, $1853,1858,1863$ y 1886), each depending on the president of the time.

All of this instability on national borders, as well as the question of what would be the best type of state for the territory, would be put to rest by the 1886 magna carta which defined Colombia as a central unitary state. However, although this would create constitutional stability, it would not be the solution to Colombia's territorial reality.

The second period, which began towards the end of the 19th century, would bring about two interesting aspects: constant territorial reclamation and a delegitimisation of central entities by illegal groups. During this period, territories took on a greater degree of autonomy, to the extent that Panama was granted independence at the beginning of the 20th century, under the presidency of Jose Manuel Marroquin (1900-1904). Although this was a result of international pressure, there already existed within Colom- 
bia a territorial reorganisation process that allowed for the division of large departments into smaller territories, which also aimed to create a counterbalance which would favour the centre in its control over the peripheries (Fals-Borda, 1996). This territorial organisation would not, however, be complete until the 1990s. Another aspect to consider arrived in the 1940s, with the start of the Colombian conflict, which would move towards the recognition of farmers and guerrilla movements. In response, paramilitary groups were formed. Since the latter part of the 20th century, all these actors found a way to finance the conflict in drug-trafficking, which put in doubt the capacity for national institutions to be present throughout the national territory (Pécaut, 2012). This period, as with the last, would end with the construction of a new political constitution, which would contain two key aspects: a framework for the consolidation of the peace process and an international focus (where the restructuring of centralist states took on great importance).

Following the 1991 constitution, the armed conflict and the delegitimisation of the central state continued throughout the country, regardless of how many attempts were made at reconstruction by the Colombian State, efforts which hoped to legitimise national and territorial institutions. Mendoza (1992) points to five territorial principles:

a) autonomy of territorial entities; b) consolidation of decentralisation; c) economic strengthening of territorial bodies; d) the municipality as a principal engine of the state; e) development of participative democracy.

Although conceptually this was the right way to strengthen the unitary state, the armed conflict continued to weaken and undermine existing entities.

All of this paved the way for President Andres Pastrana's (19982002) recentralisation policies of the 1990s which were further strengthened by Alvaro Uribe's (2002 - 2006 and 2006 - 2010) governments. One example was the changes made to the assigning of resources in the General System of Bonuses (SGR) ${ }^{2}$. At the same

2 The SGR is a compensation mechanism that was originally created to make up for the effects caused on nearby areas by the extraction of natural resources. 
time, after the perceived failure of Andres Pastrana's government in managing the peace process, Alvaro Uribe came to power, although his autocratic image would put the efficiency of talks with armed groups in doubt. During his two terms as president, Uribe adopted a strong military policy in order to have the presidency represented in every corner of the nation, thus allowing him to put in place policies which reinforced centralist ideas and served the presidency.

There were notable changes on a territorial level. Firstly, the aforementioned reassignment of resources in the SGR gave a smaller margin to territories. Institutionally, an effect of the "consejos comunales"3 was a weakening of national and territorial entities, since the population only legitimised the presidency (and thus only the president). This came about as this type of activity was always seen to be the solution to problems, without necessarily recognising who was responsible for providing answers to the problems. In the

3 The Common Councils were created by the mandate to gain a presence in Colombian territories. Inhabitants of these populations were invited to share their problems, affording them all the national institutional expertise to allow a quick response. already weak entities, this further weakening led to the restoration of a national sentiment that had been put in doubt throughout the 1990s, almost leading Colombia to become a failed state.

The current president, Juan Manuel Santos (2010-2014), has continued to take advantage of this situation to introduce other mechanisms, where territorial resources are redirected according to national entities, while at the same time attempting to create a vision of the territory which would allow the implementation of policies that contribute to the development of each of the territories. Throughout this period, there have been a number of national changes that are worth studying, due to their implication for territorial order and the long-term effect they would have on public territorial policies and especially departmental policies.

Perhaps the greatest advancement in response to the instability and lack of continuity of policies linking territories to national entities was the reform brought about by the Organic Law of Territorial Planning (LOOT) of 2011. This law sought to revive what was laid out in the 1991 
constitution, which had faded over time as a result of departmental weakening, poor use of resources by many municipalities (due to the lack of technical capabilities) and the recentralisation of the early 21 st century (Niño-Amezquita, 2010). This legislation sought to strengthen decentralisation without jeopardising the unitary Colombian state and while understanding that autonomy is one of the best ways to deal with the needs of the population and its territories (ICP, 2011).

Within this process of recreating national entities and territories, it is necessary to start to develop projects alongside the different levels of government. There are three important cases where efforts are brought together and the resolution of territorial problems is promoted through joint territorynation action. These actions principally replicate models that have been developing steadily in Latin Europe. As a result, we see associative blueprints between territorial entities (EAET), the Contrato Plan (CP) and PublicPrivate Alliances (APP) (Borda \& Diaz, 2012).
Although each one of these tools has its own logic, they are pertinent to this text for two main reasons: the strengthening of territorial entities in order to carry out functions they previously did not, and promotion of associations between entities of the same or different levels. With this comes a strengthening of territories and, in turn, this can lead to the introduction of functions that none of the levels had claimed as their own, as is the case with intersub-national relations.

Finally, one must evaluate the project in terms of a territorial concept laid out in the 1991 constitution: the region. As is the case with many of the processes that have been developed in Colombia, the region as a concept is adapted from the sub-national units of Europe's Latin countries, and creates a more complex fourlevel political - administrative structure. This project was never wholly followed through, with there currently being some test cases in the Caribbean region or the central region (near Bogota), which show the first results more than 20 years after the framework was initially put in place. Doubts have emerged over what functions this new structure should take on, 
with the belief that large-scale projects should be carried out by entities which are larger than the department but not necessarily by the nation (DNP, 2013). Subnational relations do not enter into, this framework of ceding responsibilities to regions, but this does not imply that territorial entities that currently exist (departments and municipalities) demonstrate any interest in exploiting this responsibility.

The central-peripheral struggle has existed since Colombia's creation and can largely be explained by a fragmented territory. In turn, it is a territory that has been impossible to control for a centre that selflegitimises and which has found several actors who are unwilling to allow the continuance of institutions throughout the national territory, namely local elites and groups operating outside the law (sometimes they are one and the same).

This all provides a context from which to examine how territories integrate into the new process of territorial globalisation, with the breaking down of national borders and some weak or inexistent national and territorial institutions allowing for new links to be forged outside the borders.

\subsection{Internationalisation and decentralised cooperation in Colombia}

Colombia is not immune to the dynamics that shape the rest of the world although, due to its geographical characteristics and the continued armed conflict, applying these processes has been somewhat more complicated. As with other countries, cooperation originally existed between departments who sought solutions to the armed conflict and the creation of relevant institutions. Over time, "aid, which has development as its objective, became integrated into the logic of international alliances" (Arteaga, 2011).

In Colombia, cooperation is a mechanism used to deepen international relations and contribute to the country's development (APC, 2012). With regards to the start and evolution of international cooperation in Colombia, the concept has undergone many changes, due to international influence and experiences, moving from a vision of Official Aid for Development 
(AOD) towards a vision centred around impact on development, since the country's recent inclusion in the $\mathrm{OECD}^{4}$. It is necessary to underline that, although the national economic reality is one of a large economy on a continental level, this has not implied that traditional cooperation has continued to be essential in Colombia, due to the aforementioned conflict. So, the applicable results end up being humanitarian and emergency aid, food aid, cultural cooperation, grants and donations.

The 1970s saw real steps towards international cooperation in Colombia, when the government created a special division in the National Department of Planning (DNP), called International Technical Cooperation. This division would be responsible for coordinating international cooperation (Guaqueta, 1995). This continued to be dealt with by the DNP, until it was adopted by the Ministry for International Relations at the end of the century. With the arrival of Uribe's government and the strengthening of the presidency, this function fell

4 Based on the definitions of the APC. http://www. apccolombia.gov.co/?idcategoria=114\#\&panel1-6 into the hands of Social Action, an entity linked to the presidency.

The final restructuring saw the creation of the Presidential Agency for Cooperation (APC), which was responsible for channelling supply and demand through a direct dialogue with national institutions (especially the Ministry of Exterior Relations) and territorial entities (APC, 2012).

This previous context demonstrates how cooperation has been no exception in terms of the constant changes in public ordering and administration in Colombia. The territories, therefore, have had to develop their own initiatives in order to forge links with actors outside the national borders, although there are few examples of successful cases. An example to take into account is Colombia's first decentralised international cooperation agency, the Cooperation and Investment Agency of Medellin and the Metropolitan Area (ACI), set up in 2002. The ACI helps ensure that the city is part of the global flow of technical and financial resources, allowing for local development (ACI, 2007). 
Map 1. highlights how irrelevant internationalisation (and decentralised cooperation) is within the departmental organisation ${ }^{5}$. Gutierrez (2011) explains that the internationalisation of territories has not taken on much significance in Colombia, due to the insistence on basing this process on the idea of sovereignty, highlighting the fact that these sorts of relations could create problems with the centre.

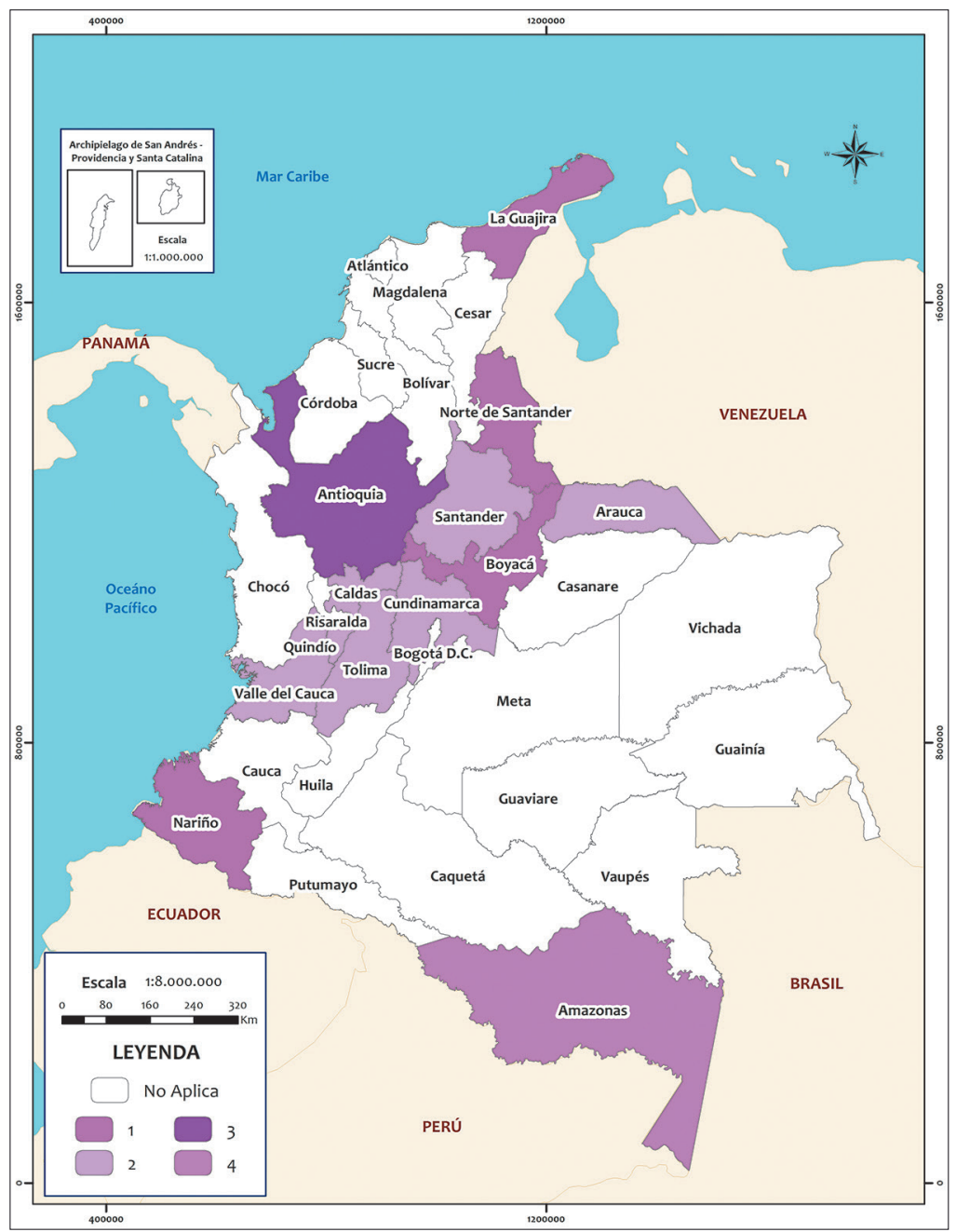

Map 1. Level of internationalization of Colombia's departments.

Source: by author, based on the departmental administrative organisation chart.

5 To do so, the position of the person responsible and their closeness to the head of the executive is studied. If they depend directly on them, the value is 1 and so forth. 
In Colombia, there are 32 departments plus the capital, but only $42 \%$ of them evidence some degree of internationalisation. Furthermore, of the departments that demonstrate some level of internationalisation, $64 \%$ have a value of two. This highlights the importance of efforts made by international actors, notably the European Union, to strengthen departmental and municipal initiatives, as evidenced by ACI (2002) at the start of the century.

The departments of Nariño and Boyacá have an office that depends directly on the executive and demonstrate the first level of internationalisation. The two share similar climates, geographical conditions and a shared agricultural dominance. Northern Santander has its own secretariat, which is dedicated to international cooperation and border issues, given that the department is the main gateway to Venezuela.

Only $27 \%$ of the departments, and this includes the capital, have a level of internationalisation of two, which suggests that, while internationalisation does not depend directly on the executive, they do have an office dealing with exter- nal affairs. Within this group are Arauca, a border department of Orinoquia, Caldas and Quindio, located in the centre of the country (in the area known as the Coffee Region), Bogota and its department, Cundinamarca, La Guajira in the north and Tolima, Santander and the Valle del Cauca which are located along the Andes.

Amazonas and Antioquia are the departments with the lowest rank of internationalisation in the country, scoring four and three respectively. However, it is worth pointing out that Antioquia is no stranger to the dynamics of internationalisation, with its very own Institute for the Development of Antioquia (IDEA) which is run by the head of cooperation and international business.

Additionally, 58\% of Colombian departments do not show any kind of administration dedicated solely to the theme of internationalisation, with the majority of these located in the south-east of the country. There are a number of aspects that either promote internationalisation and the use of decentralised cooperation tools or hinder it within departmental entities: geographic location, economic vision and the 
decentralised cooperation framework of the territory, and the capital city-department relationship.

\subsubsection{Geographic location}

Taking into account the definition of decentralised cooperation and its interest in crossing national borders, it follows that this is an action which is initially seen in border regions. However, Colombia's frontier zones do not behave in the same way, or if they do it can be explained by other factors. Within this group we have Arauca, which borders Colombian Orinoquia, and whose economy is centred mainly on petroleum and livestock. It does not, however, have any strong ties with Venezuela. The other departments making up the national corners are Guajira (north), Nariño (southwest), Amazonas (south) and Northern Santander (north-east). Guajira has strong commercial ties with Venezuela, although its main global vision is framed by its natural resources. In Nariño, commercial ties with Ecuador exist, since the region is geographically better linked to its neighbouring country than to the rest of Colombia. Although part of this breaking down of borders has existed for some time, institutionalising this vision will respond to a traditional view of cooperation as a source of aid.

The cases of Amazonas and Northern Santander are interesting. The former is relevant given its international links, brought about by the inexistence of any kind of border limits in the jungle and the strong tri-frontier links seen in the capital, Leticia (ColombiaPeru - Brazil). For Northern Santander, internationalisation and decentralised cooperation are imperative. This department presents the perfect example of a territory that lies beside an existing geographic border which, in reality, becomes blurred by the constant flow of people and goods across said border. This is why there emerges a need for a secretariat to deal with these topics ${ }^{6}$.

Geographically, there is clearly a behavioural link to the Andes. Looking at a map of Colombia, it can be seen that the majority of departments where some part of the government is specifically dedicated to internationalisation are located along this mountain

6 The Secretariats are the second level of government in Colombia's departmental order. 
range. This is hardly surprising, given that the Andes are where the majority of the population is located as well as the country's economic activities. Therefore, the majority of southern or eastern departments show little interest in this type of entity $^{7}$. Consequently, these roles are taken on by the nation and, in a few cases, municipalities. An example of the distinct lack of interest in this tool is Colombia's Pacific coast, although there are some links to cooperation for aid, which can be taken on by the national agency.

\subsubsection{The economic vocation and internationalisation}

Colombia's development has been mainly centred around the Andean region. So, the departmental entities in this part of the country can rely on greater technical and financial capacities with which to make their entrance into international spheres. However, given the fragmented geographical reality, the economic situation in the departments is not the same. This territorial disparity has an effect on the application of

716 departments from this group contribute less than $2 \%$ of the total GDP. 11 of these departments demonstrate a higher level of poverty than the national average of $37,2 \%$ for 2010 (Riffo, 2013) internationalisation and the use of decentralised cooperation.

Each department has an economic vocation, demonstrating which of their principal products creates interest internationally. This is the case in terms of natural resources in Guajira and Arauca, and in terms of coffee production in Tolima, Quindio and Caldas. These last two have organised the coffee producing eco-region, with their international position also being determined by another key line in its economy: tourism (Rodríguez et al, 2003).

This economic line forms part of the internationalisation process of the country's most developed regions, Valle del Cauca, Antioquia, Cundinamarca and the Capital District. These territories have gone well beyond simply positioning themselves as tourist destinations and have been dedicated to encouraging investment in their territories. This was made possible by the wide range of production and the concentration of demand for goods in these areas. Evidence of this is the internationalisation and decentralised cooperation evident in development plans, exemplified by the Institute for 
Antioquia's Development (IDEA), which deals with the management of cooperation and international business and implements strategies to invigorate departmental behaviour (Gutierrez, 2011). Also, Cundinamarca has an international cooperation office for strategizing and spreading cooperation. Olaya and Velez (2009) sum it up perfectly by explaining that "these two territorial entities have developed an explicit vision of internationalisation, which is mainly associated with economic development and competition". These territories, therefore, are best placed to establish bridges for decentralised cooperation in joint projects, where all the members give and all the members receive. This goes against the situation in the less-developed Colombian territories, since they will seek territorial internationalisation simply in order to commercialise their commodities or to facilitate cooperation for aid, for which they will have to compete with other levels of government.

\subsubsection{The capital city/department balance}

One of the effects generated by decentralisation in Colombia was the lack of complementation and cooperation between the levels of government. This can be seen in the department's loss of importance and the prioritisation of power and resources at the municipal level. This implied that, alongside the constant flow of migration towards the large population centres, the municipal entities of departmental capitals redefined their power relationship with the sub-national entity (the department).

The weakening of the department is clear, although this does not imply that it does not have management capabilities or that departments are not the response to certain territorial characteristics. Bogotá, as the Capital District, has created centralisation policies that have had an impact on all the departments, influencing the internal dynamics of each one of them. Each one of the capitals of developed departments has organisations which are focused on internationalisation and decentralised cooperation. Evidence of this is the ACI, which, after its incorporation into the 2004 development plan, gave the guidelines for the global integration of the city of Medellin and its metropolitan area (ACI, 2011). 
In contrast, the less-developed regions have much weaker departmental capitals, leaving the job of main actor in internationalisation to the department. So the Andean region's population dispersal means it would only become efficient through its grouping, as is the case of the department. The same occurs in Colombia's plains. The most relevant example to this study is the department of Boyacá, which we will look at in the next section, since its capital did not manage to consolidate itself as a large centre and its population spread out across the territory, the rural nature of its municipalities making the situation yet more complex.

So while some Colombian departments are in the process of internationalisation, there is still a long way to go, since, as Ferrari (2003) points out:

Topics such as this are still far from being part of interterritorial daily life in areas which make up countries, and within these there does not exist the purpose of paving the way to the internal possibility of creating cooperation within themselves.
Therefore, it is necessary to favour the internationalisation of Colombian territories, which demands the construction of adequate institutions and the economic material for it (Rhi-Sausi \& Conato, 2008). Establishing the main role of departments in general and Boyacá in particular becomes necessary in ensuring the best use of a tool that has only been used by developed areas and which could generate changes in the quality of life of the population.

\section{The Relevance of Boyaca's Departmental Entities}

Continuing on from the analysis of Colombia's process of territorial construction after the breaking down of national borders, this text will present the case of the department of Boyacá, a complex territory which has seen itself demoted in the eyes of national priorities. Proof of this is the lack of specialised scientific production $^{8}$, opposing the claim that it wants to make its capital a city of knowledge. Therefore, this section is based on conceptual

8 It is necessary to emphasise and underline the work of Orlando Fals Borda, who dedicated a large part of his life to investigations aimed at finding a response to Boyaca's problems. 
texts, focused on the realities of similar territories, and carried out in the same way as 2013's fieldwork. The last part of the text is centred around the survey carried out in the municipalities of the department.

\subsection{A characterisation of the department}

Boyacá is one of Colombia's 32 departments. It is located in the centre of the country, with most of the department centred around the Andes mountain range. Boyacá is home to most climates and a fragmented territory, although its main cities are located in the plateau known as "Sabana Cundiboyacense". This is shared with the department of Cundinamarca, within which lies Colombia's capital, Bogotá.

The department of Boyacá is 23,012 metres squared, a little over half the size of Switzerland. To the north it borders Antioquia, Santander, Northern Santander and Venezuela. Arauca and Casanare border it to the south and south-west respectively, while it meets Cundinamarca, Caldas and Antioquia in the east. Its geography is significant, due to its proximity to three of Colombia's major economic actors: Santander, Antioquia and Cundinamarca, with the previous two (taking Bogotá into account) making up $40 \%$ of the national GDP ${ }^{9}$.

In terms of administration, Boyacá is divided into 123 municipalities $^{10}$ and 12 provinces. Due to their geographical characteristics, there are also special zones in the municipalities of Puerto Boyacá (next to the Magdalena River), Cubara (bordering Venezuela) and the sub-province of La Libertad, which is made up of four municipalities, two from the province of Sugamuxi (Labranzagrande and Pajarito) and two from Valderrama (Paya and Pisba).

Demographically, Boyacá is home to $1,255,311$ inhabitants, of which almost 50\% $(657,806)$ live in the central area ${ }^{11}$. Looking at those located in the urban centres, the percentage is even higher: 646,412 people live in urban zones and of those around 420,000 live in the central zone. Given that the majority of Boyacá's inhabitants

9 Sourced from the National Department of Statistics (DANE).

10 Boyacá is the department with the second-most municipalities after Antioquia, with 125 (Source: DANE).

11 Made up of the provinces of Centro (capital Tunja), Tundama (Duitama) and Sugamuxi (Sogamoso). 
live in the urban areas of Tunja, Duitama and Sogamoso, there is a strong inclination towards centralising the economic sector. In contrast, the other provinces show a much higher number of people living in rural areas than urban areas. The rural population, in fact, represents around two thirds of the total population of the remaining nine provinces.

Boyacá is culturally diverse, due mainly to its geography, where factors such as its area, its location and its proximity to other departments contribute to blurring a departmental identity. This is why the rural tradition is strong in the centre and south (towards Bogotá). These are also the same elements that characterise the grouping of Cundiboyacense and represent the image that the department has outside its borders. To the west of the department, near the Magdalena River and bordering the departments of Caldas and Antioquia, lies the emerald production zone. The higher temperatures and mountainous terrain have strengthened a different identity, which takes after the "paisa" tradition much more. Finally, in the north, due to the distances involved and the lack of transport links, a tradition has been established, which although it retains its rural character, presents a culture more closely linked to the south of the department of Santander. Within these provinces there are indigenous groups which add further complexity to a diverse department.

The central region appears to be the favoured area, being as it is the only place where one will encounter the main economic activities of the region, industrial carbon and cement. This production of commodities was the development factor from the 1950s, although it never spread the benefits to the rest of the department, as is the case in Acerias Paz del Rio. As shown by Cuervo \& Gonzalez (1997), this public industry was just a "chapel in the desert".

Thus, after years of poor administration, the 1990s gave rise to the privatisation of the company, which was strengthened by the general reduction in production of goods by states. Over time, it became a large company, attracting foreign investment like that of the Brazilian group Votorantim. However, the territorial problem remains the same, since its production is not 
aligned with any nearby actor and its economic activity is completely detached from synergies in favour of local and departmental development.

Other factors which drive the economy are tourism and commerce $^{12}$, also found mainly in the centre of the department. Tourism grew thanks to the region's proximity to Bogotá, coupled with the department's process of expansion aimed at turning it into a destination for weekend getaways. Commerce can largely be explained by the internal dynamic of the department. That is to say that activities which take place are linked to internal demand and position themselves mainly in the large urban areas in the centre of the department, with Paipa being the municipality with the greatest vocation towards this activity.

It is therefore important to understand what happened and what caused this tendency. According to the 2005 census $^{13}$, the department's population dropped, as did its contribution to Colombia's

12 Annual Manufacturing Survey 2012. Source: DANE.

13 According to DANE, Boyaca's population dropped from $1,315,579$ to $1,255,311$ between 1993 and 2005, in contrast the rest of the country's growth.
GDP (DANE, 2005). As a result, territorial order and regional integration have taken on greater importance - although they are not very clearly laid out - due to the wide range of territorial identities that exist within the department. Efforts by developed areas to integrate and create joint development, which would lead to growth throughout the whole department, were decreased. This problem is epitomised by the axis formed by Tunja, Duitama and Sogamoso, which has turned into something of an enclave which avoids relations with the rest of the department and blocks the distribution of received funds towards agriculture, Boyacá's principle economic activity.

Thus, the department is home to the iron and steel industry, which has allowed for the construction and development of TunjaDuitama-Sogamoso's industrial arm. This industry has historically been associated with Boyacá but there has not been a diversification of production or any sustained development of other industries that require iron or other regional resources, leaving the department with no productive links, as said before. The other main economic elements are agriculture and 
tourism, which are directly linked to demand in the country's capital. The department is also home to the beverage industry (alcoholic and non-alcoholic), which has been driven by internal demand.

Taking the case of Boyacá, it is clear to see the political and administrative influence that Bogotá has and Boyacá's dependency on the capital. Bogotá's influence can be seen in the processes of territorial integration which have been developed until now, and which assume that Bogotás area of influence includes the department of Boyacá, as can be seen in the development of the city-region, the Andean Region and the RAPE ${ }^{14}$. This process has been gaining formal recognition in 2014 and shows how a flexible grouping of territorial entities can play a central role in development, although it can also contribute to the subordination of territories to peers with more political power. This is relevant to placing value on international integrations that Boyacá, or its municipalities, can achieve.

For Boyacá, Bogota represents the centre of national power

14 Platform for Regional Development. and, consequently, the place where decisions in favour of the development of the department are made. Since colonial times, Tunja and its department have represented a centre of power based around coexistence and competition with the large capital, Bogota (Velandia, 1971). Since independence, in addition to Cauca, Boyacá has had the highest concentration of presidents, a clear example of the political power that these two departments have held throughout Colombia's history (Ocampo, 2006). This situation explains the behaviour and vision of Boyacá with regards to the transfer of national resources in order to respond to territorial needs. As such, Boyacá was one of the departments which was most hard-hit by the process of decentralisation that began in the 1980s.

This thinking could prove fundamental to the development that Boyacá could have, but which it does not necessarily seek. The Office of National and International Relations (Boyacá) was founded in the 1950 s, within a context where it was relevant to influence the decisions of the centre with regards to transferring resources from national entities. This behaviour 
has not changed over time. After the process of decentralisation, doubts surfaced on a national and territorial level over the best way to establish relations with partners. Currently, faced with departmental lagging and the new ways in which the nation supports territorial redistribution, we see a return to a search for national resources (and sometimes international resources) in order to support Boyacá's needs. In the next section, we will go into more depth about the potential role of this institution.

\subsection{Internationalisation inside Boyacá.}

As we have seen, the process of internationalisation is facing by all of the departments, although this does not necessarily mean that they are taking action to deal with it and take advantage of the resources that this new process generates. Boyacá is no exception. For the purposes of this study a municipal survey was carried out in order to understand, from the institution which is closest to the population, if the departmental level is the one which should be made responsible for the efficient administration of new resources relating to territorial cooperation or decentralised cooperation. The survey was carried out by mayors or the planning secretary in Boyacá's municipalities.

The surveys offer results which allow us to establish what sort of dynamics are at play in terms of cooperation and internationalisation ${ }^{15}$. Initially, what stands out is the unanimity of the territories ( $100 \%$ of those surveyed) in recognising the importance of establishing international links to help develop territories. It is worth pointing out that this unanimity does not imply that policies developed at a municipal or provincial level will focus on responding to this need. How important this is perceived to be depends on the characteristics of internationalisation and decentralised cooperation that we have already seen. Integration into these global spheres allows for the appropriation of new knowledge and skills and the establishment of links for local products with potential partners. The traditional view of cooperation still exists, placing emphasis on international aid. Although Boyacá is not a

15 Of the 123 municipalities, $95 \%$ of them responded to the survey. However, it was not possible to obtain results in the municipalities of Motavita, Santa Maria, La Capilla, Gameza, Pisba and Coper. 
priority in terms of international cooperation, it responds to the Colombian conflict and the situation of poverty experienced by many of Boyacá's municipalities, mainly those which are further from the central axis of cities.

There are three aspects to consider with regards to generating public policies to promote internationalisation and decentralised cooperation: geographic characteristics, the level of development and the role played by the departmental entity. One must therefore take these into account in order to understand a territory and provide an efficient answer to the question of the department's development.

\subsubsection{Geographical characteristics}

As previously mentioned, Boyacá is a fragmented territory, something which has affected the urbanisation process, a prevailing factor in allowing access to internationalisation and decentralised cooperation. One also finds that there is no direct correlation between the size of a municipality's population and its knowledge of decentralised cooperation. After carrying out the survey, it was noted that both large municipalities and small ones have some notion of what this practice involves. For example, both Tunja and Cuitiva have an understanding of the theme, although the former has 182,000 inhabitants while the latter has less than 2,000.

With the exception of the departmental capital, Tunja, high levels of urbanisation do not guarantee a better understanding of decentralised cooperation. In fact, thehighestnumberofmunicipalities claiming an understanding of the topic are categorised as high-rural or mid-rural, according to urbanrural classifications. Amongst these municipalities are Quipama, Maripi, San Miguel de Sema, Sotaquira, Toca, Tuta, Somondoco, Tenza, Cuitiva, Topaga, Tota, Sativa norte, Nuevo Colon, Chinavita, Guican and Panqueba.

Map 2 shows the location of the municipalities, highlighting the fact that the majority of municipalities with some understanding of decentralised cooperation are located in the central and western part of the department. This is clear evidence of the links these areas have with Bogotá. The centre of the department not only benefits 
from a constant relationship with the national capital, it is also home to the majority of economic activities. The west of the department shares direct links with Bogotá, without having the departmental capital acting as an intermediary. The main example of this is Chiquinquirá, which is closely linked to Bogota through various economic activities. Parts of this area differentiate greatly from the department. The importance of a departmental figure has been fading, placing significance on a provincial identification, as we will see later (Map 3), exemplified by administrative autonomy and the individual identity of the municipality of Puerto Boyacá.

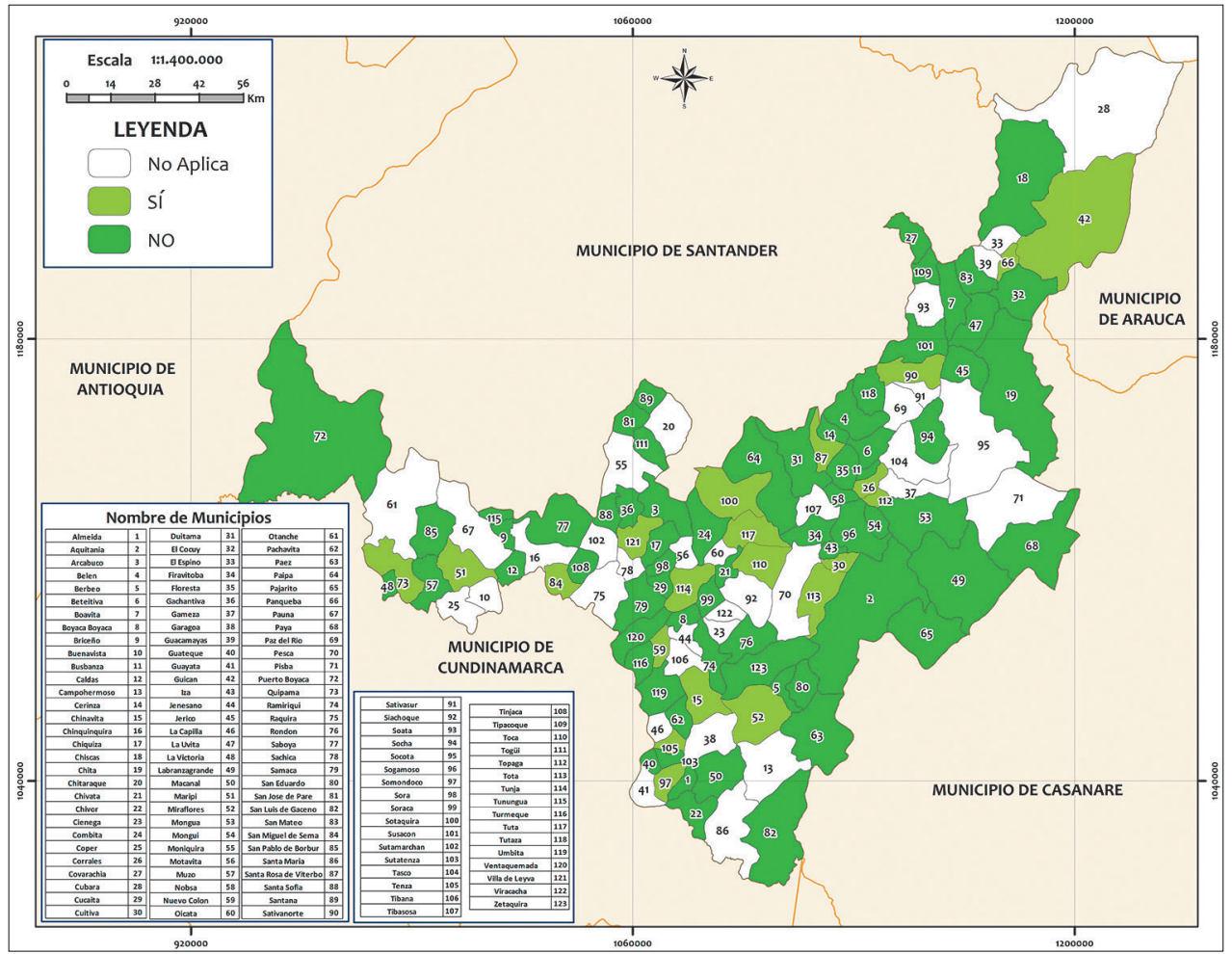

Map 2. Understanding of decentralized cooperation

Source: by author, based on primary data.

Finally, although a spatial analysis the department was faced by of the behaviour of municipalities the same problem, according to has been carried out, it can be Fals-Borda (1957). Territorial seen that, half a century ago, fragmentation has meant that there 
is no dominant central-periphery model or any consolidated process of urbanisation. In many random situations, we see behaviour that highlights the lack of and need for intervention from entities that group together these municipalities, as we will see in the last part of this section.

\subsubsection{The level of development}

The survey's principal findings show that municipalities with a mid-level developmental index have a closer relationship with decentralised cooperation than those with high or low index ${ }^{16}$. Considering this, we find municipalities such as Toca, Miraflores, Quípama, Panqueba and Topaga amongst others whose indices oscillate between 0.3 and 0.5 and have thus been able to benefit from this type of tool. This also allows us to see how difficult it is for the most backward zones to initiate integration processes with actors at an international level.

Map 3 shows the activity of municipalities outside national borders. In it we can see which borders have succeeded in making international connections, whether they

16 Source: Departmental Report on the Human Development Index, PNUD. are with multilateral organisations, cooperation agencies, NGOs or international peers. We can also see that less than a third of municipalities have been able to make these connections and inter-territorial connections are even less common. The departmental capital's actions are guided towards strengthening connections with international peers to position itself as a centre of academia and investigation.

In these connections we can see two previously analysed perspectives; one related to links through aid and the other related to economic interests. Initially the aid perspective will be linked to municipalities with low levels of development and a highly rural population. The central topics will be basic necessities and attention towards vulnerable populations which, in some cases, have been the effect of a post-conflict vision of cooperation.

The former map shows how these themes are not necessarily linked with support offered under the new manifestation of decentralised cooperation given that territories now only seek to meet their basic necessities without taking into account which actor provides it (national or departmental government, multi- 
lateral governments or internation- leaves this type of decision mainly al territorial peers). This is due to up to the national level. From there, the low technical capacity of many issues are addressed at a national governmental municipalities which level, regardless of the territory.

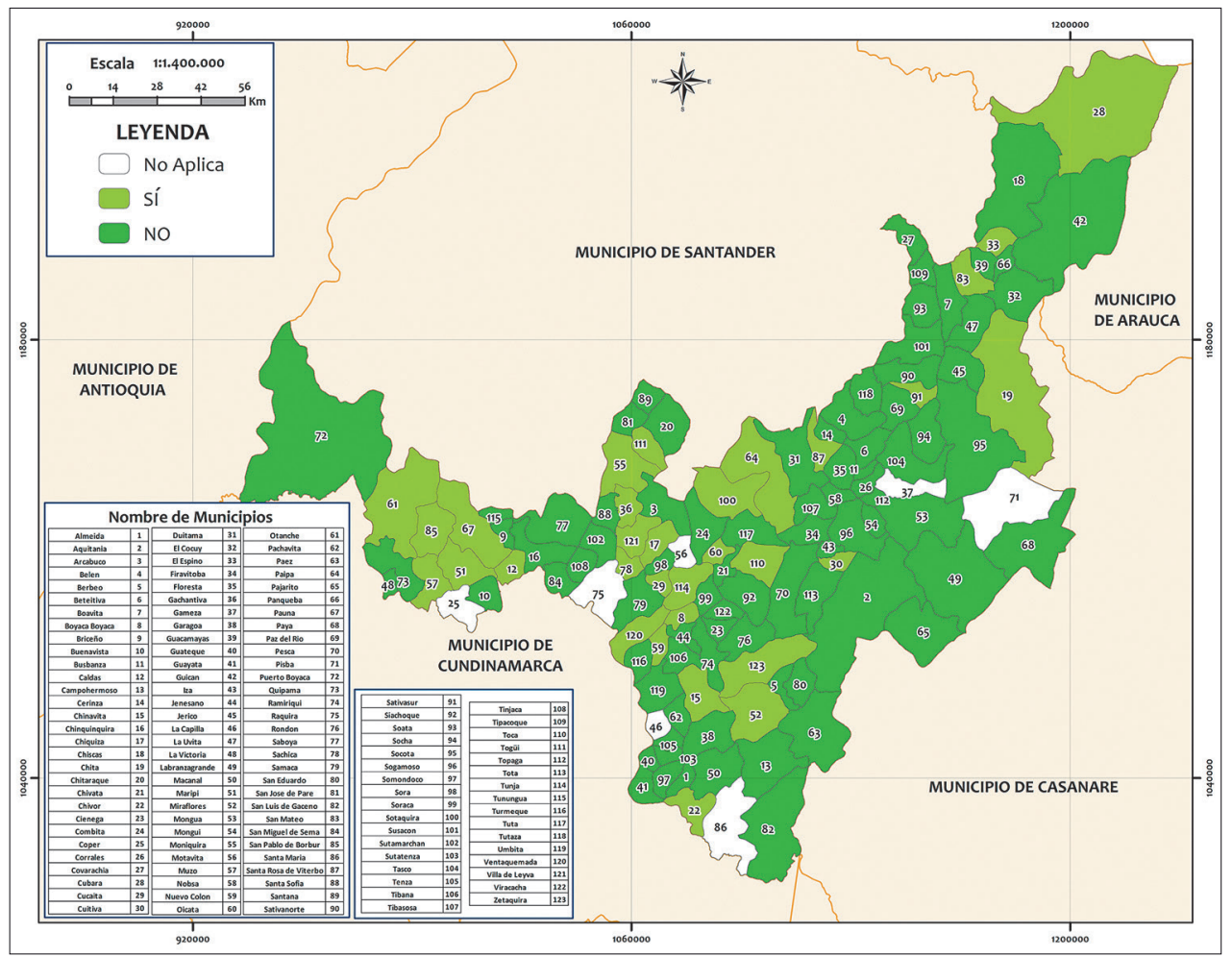

Map 3. Municipalities with international links

Source: by author, based on primary data.

Table 1. Perception of decentralised cooperation ${ }^{17}$

\begin{tabular}{|l|c|c|c|c|}
\hline \multicolumn{1}{|c|}{ Province } & $\begin{array}{c}\text { Aid for } \\
\text { development }\end{array}$ & Joint projects & Both & None \\
\hline Centro & 1 & 4 & 9 & 0 \\
\hline Oriente & 0 & 1 & 6 & 0 \\
\hline Sugamuxi & 2 & 6 & 4 & 0 \\
\hline Ricaurte & 2 & 1 & 10 & 0 \\
\hline Tundama & 2 & 2 & 5 & 0 \\
\hline Lengupa & 0 & 1 & 5 & 0 \\
\hline Valderrama & 0 & 2 & 5 & 0 \\
\hline Norte & 0 & 4 & 5 & 0 \\
\hline
\end{tabular}




\begin{tabular}{|l|c|c|c|c|}
\hline \multicolumn{1}{|c|}{ Province } & $\begin{array}{c}\text { Aid for } \\
\text { development }\end{array}$ & Joint projects & Both & None \\
\hline Márquez & 0 & 3 & 7 & 0 \\
\hline Occidente & 2 & 4 & 8 & 0 \\
\hline Neira & 0 & 1 & 3 & 1 \\
\hline Gutiérrez & 1 & 0 & 4 & 1 \\
\hline La libertad & 1 & 2 & 0 & 0 \\
\hline Cubara & 0 & 0 & 1 & 0 \\
\hline Puerto Boyacá & 0 & 0 & 0 & 1 \\
\hline Total & $\mathbf{1 1}$ & $\mathbf{3 1}$ & $\mathbf{7 2}$ & $\mathbf{3}$ \\
\hline
\end{tabular}

Source: by author, based on primary data.

The economic connection provides a better-elaborated vision of the tool. Cases like that of the municipality of Chiquinquirá ${ }^{18}$ become relevant to this study given that its vision (alongside that of Tunja) is the most competent with respect to concepts of territorial internationalisation and the use of decentralised cooperation. In the first place, the municipality attracts foreign investment that combats unemployment. In turn, these types of activities serve to develop the territory through the transfer of technologies and experiences. This perspective is shared by the municipalities whose principal sector is tourism and, also, those with influence in Bogotá which thus have the quickest access to

17 The results are based on the survey conducted, the question was closed; leading the options presented in the results.

18 Located in the west of Boyacá and with a strong relationship with the national capital, Bogotá. the latest policies proposed in the capital.

\subsubsection{The role of sub-national entities}

After taking into account the geographic snapshot and the economic potential and limitations of the various municipalities in Boyacá, it can be seen that subnational entities can play a major role in integrating into international spheres and developing their territories in a uniform manner. Faced with this situation, this study aimed to examine their importance in two spheres: firstly, the House of Boyacá, responsible for the department's national and international relations and those of its municipalities, and secondly the association of municipalities (provinces) as a tool for efficiently managing projects. 


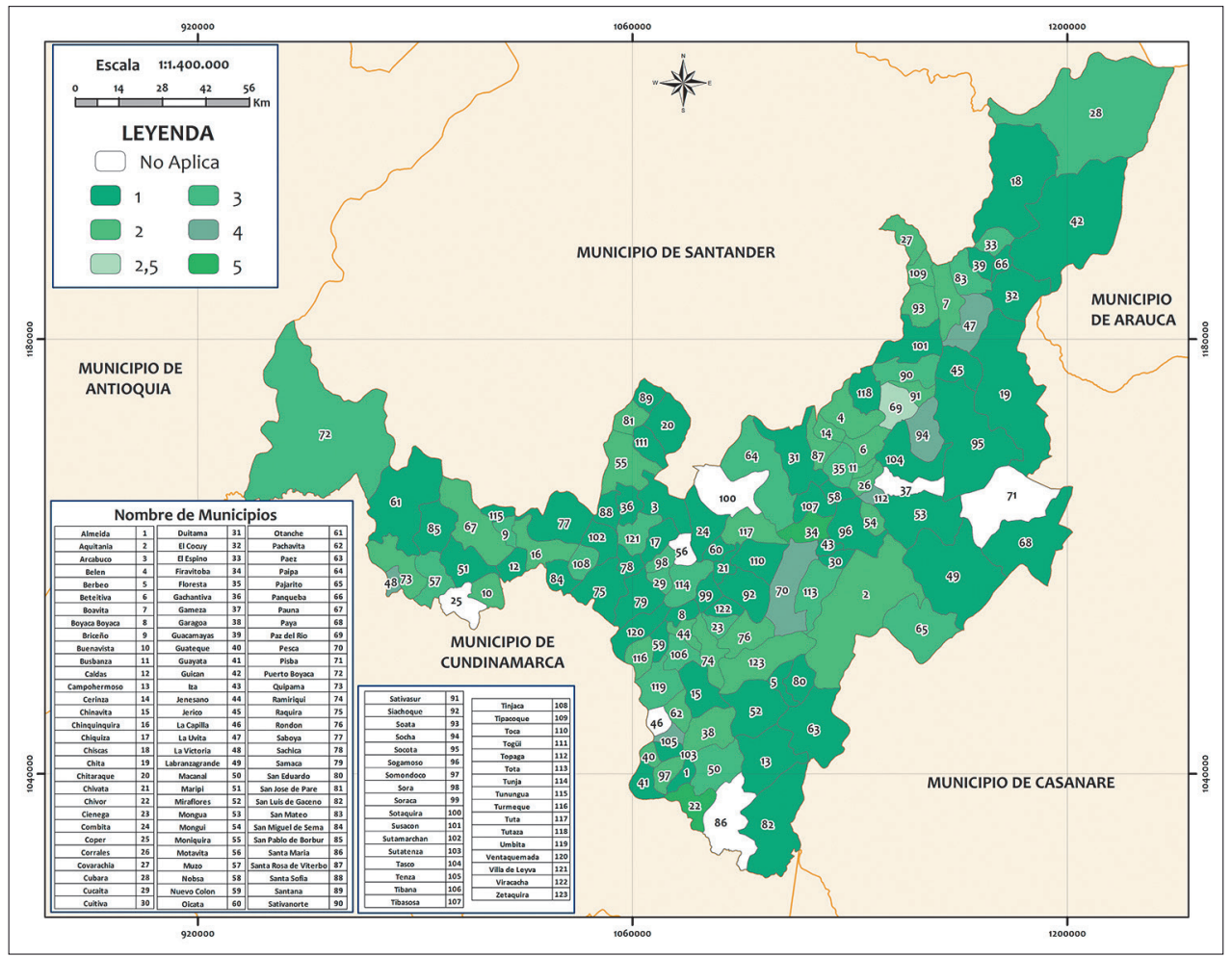

Map 4. Level of dialogue with the House of Boyaca. ${ }^{19}$

Source: by author, based on primary data.

With regards the use of the departmental entity, only 2\% (Chivor and Firavitova) claim to have an excellent level of communication with the House of Boyacá. A large percentage $(25 \%)$ of municipalities maintain a low level of communication with the entity, scoring a value of 2 , while $50 \%$ score a value of 1 . This highlights the urgent need to strengthen institutional and inter-governmental ties.

191 refers to a low level of dialogue and 5 refers to a high level of dialogue.
These results are consistent with the territorial reality of the department. Due to the disparate population spread across the territory, municipalities often cannot rely on mechanisms to be able to enter into discussions with the House of Boyacá.

This is primarily due to the difficulty of travelling to Bogota and secondly due to the unlikelihood of participating in the few activities that the institution 
carries out within the department. This takes us back to the difficulties posed by decentralising policies in municipalities with a low population, populations which find themselves unconnected to their own municipal heads. In terms of efficient use of resources and the most appropriate answer to problems within territories, the reconstruction of provinces can act as a tool to help introduce necessary policies for internationalisation and management of decentralised cooperation.

Map 5 shows the municipal advancements in the strengthening of provincial associations. As previously witnessed, Boyacá is divided into 12 provinces and two municipalities with a special character, Cubara due to its properties as a border territory and Puerto Boyacá due to its geographic location and distinctness, both culturally and economically. These two cases are relevant for understanding the viability of provinces within the department. Firstly, Cubara has made efforts towards integration with its neighbouring municipalities to the south. This shows its interest in participating in departmental dynamics and that its character as a border territory has not necessarily been an integral factor in its internationalisation, but in fact a hindrance to its integration with its province and its country. Puerto Boyacá, on the other hand, shows a historic interest in the breaking down of departmental borders and in the international perspective, due to its petroleum production.

For the other municipalities, grouping amongst municipalities is of little importance. Those that have made significant advances are few: Sutatenza, Tota, Santa Sofía y Caldas. The majority of municipalities show that, even if the topic is of interest or importance, it is not necessarily a priority. One fifth of the municipalities demonstrate a scarce interest in the construction of provinces, largely explained by the lack of financial and technical resources.

Although decentralisation has tried to establish mechanisms to ensure the solution to problems at the closest level of government, the characteristics of the department of Boyacá mean that few can be answered efficiently by the municipalities themselves. The promotion of this municipal grouping (province) should betaken 
as a departmental responsibility, at national entity to plan and identify the same time allowing the sub- the best course of action.

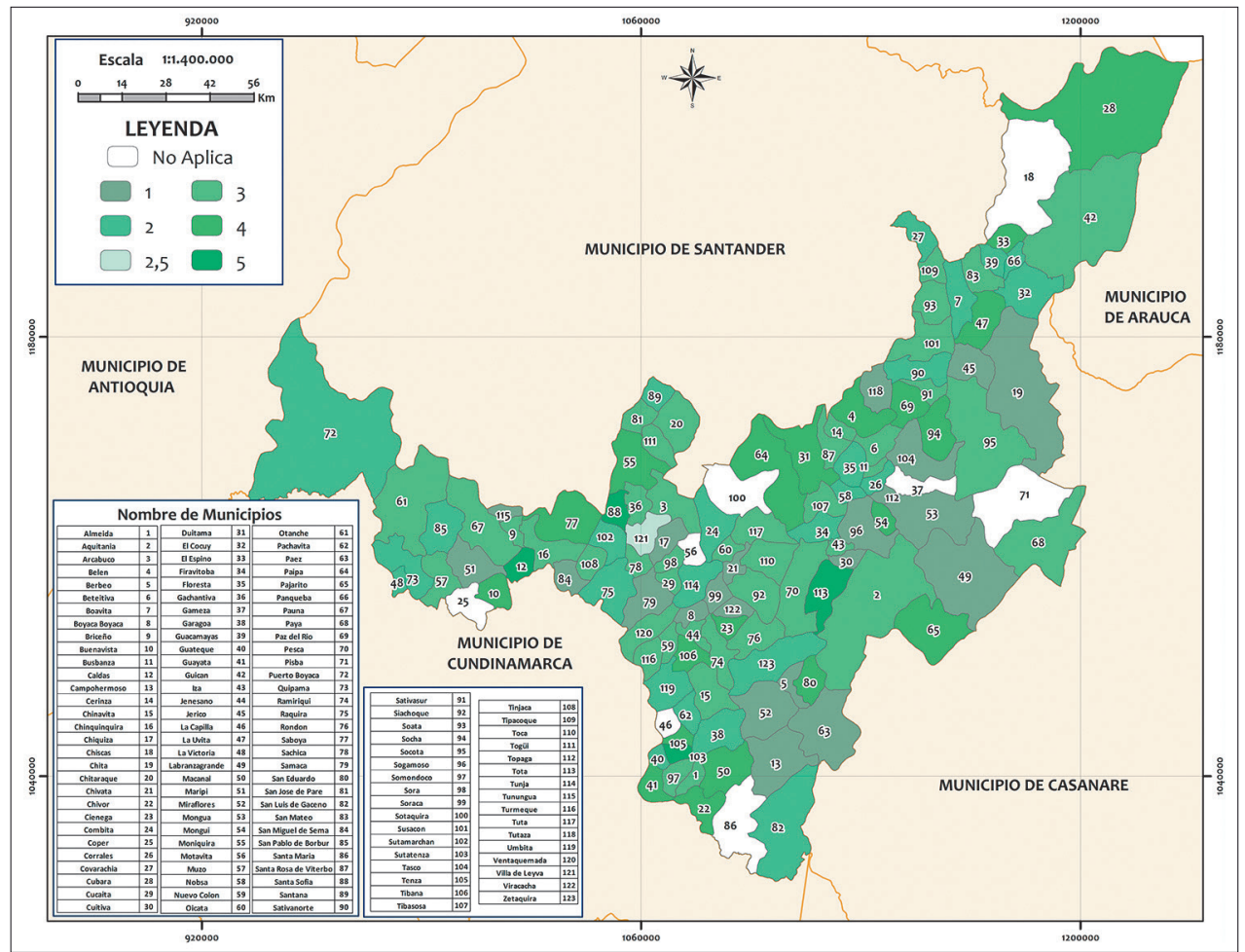

Map 5. Level of provincial strengthening ${ }^{20}$

Source: by author, based on primary data.

Finally, under the sphere of their inclusion, both nationally and internationalisation, the House internationally.

of Boyacá becomes the most appropriate body for cooperating with the department of planning and being able to respond efficiently to the new global realities that the territories in Boyacá will have to confront at some point, using and promoting the grouping of municipalities and supporting

\section{Conclusion}

The department of Boyacá shows a complex snapshot which can only be resolved through the

201 refers low level of perception of provincial strengthening and 5 refers high level of perception of provincial strengthening. 
articulation of territorial actors and their connection with national and international peers. This contributes to solving current problems and to taking advantage of the opportunities upon which the department depends. In order to achieve this, a constant interaction between sectorial entities of the government and the municipal governments must contribute to the make-up of the department. In this way, accessing global spheres comes into play, allowing us to clearly see the role of the House of Boyacá in supporting these processes, which can be built from the municipalities (especially intermediary cities) the provinces (strengthened by the departmental government) or from the same department. This will depend on the complexity of the problem and the capacity of the territorial entity.

At the same time, under these conditions, the functions of the House of Boyacá should not necessarily be reintroduced but they should be recognised both within and outside the departmental government. This should strengthen the technical and financial aspects of the entity. To aid this process, the office of national and international relations must create the necessary synergetic connections between the department and its municipalities with international peers. In this reinforcement, the current territorialisation plays a crucial role in bringing the international cooperation policy to a national level.

Therefore, the Presidential Agency ofCooperationbecomesasupporting actor to the House of Boyacá given that, as a participating member of the Departmental Committee of International Cooperation, it can provide tools that are otherwise unavailable in the territory. This is because when territorial liberties were ceded during decentralisation only the most developed territories benefitted. The constant interaction between said actors generates a space to show how their relations valorise territorial opportunities.

However, if the territorial agenda is not built in accordance with an accurate and precise identification of current problems and capacities, international peers will derail and thus fail to make real changes to the reality of department. It may become futile and provide no practical use to improving the quality of life of the department's inhabitants. 
To conclude, it is important to make clear that this chapter on decentralised cooperation and the internationalisation of Boyacá seeks to encourage further investigation on the subject. Such future investigations should be carried out within Boyacá, aiming to strengthen the remaining capacities which have not been depleted by limiting financial and technical factors. Going beyond decentralised cooperation, the question of the province as a territorial planning organisation arises. This would not only help territories to address new issues but would also contribute to better management of departmental functions. Territorial associations are seen as a step too far for the current reality in Boyacá. The priority is to know and recognise decentralised cooperation in order to then develop projects with international peers who share the same goals. The new supradepartmental territorial structures can become the future mechanism for all departmental projects of this type.

\section{References}

ACI - Agencia de Cooperación e Inversión de Medellín y del Área Metropolitana. (2007). Manual de cooperación internacional descentralizada. Medellín: Alcaldía de Medellín.

ACI - Agencia de Cooperación e Inversión de Medellín y del Área Metropolitana. (2011). Medellín, la región y el mundo: una mirada de la ACI. Algunos conceptos y lineamientos básicos para afrontar el reto de la internacionalización desde lo local. Medellín: Alcaldía de Medellín.

APC - Agencia Presidencial de Cooperación. (2012). Estrategia Nacional de Cooperación Internacional 2012-2014. Recuperado de: https://www.apccolombia.gov.co/recursos_user/ ENCI-2012-2014/ENCI-2012-2014.pdf

Arteaga, A. M. (2011). La cooperación internacional al desarrollo y su aplicación en políticas sociales del ámbito local: Un estudio de caso de programas de formación para el trabajo de la alcaldía de Medellín 2001 - 2010. (Tesis de Maestría, Universidad Nacional de Colombia). Recuperado de: http://www.bdigital.unal.edu.co/5879/

Borda, E. \& Díaz, A. (2012). Nuevos instrumentos de gestión en Colombia: contratos plan, esquemas asociativos de entidades territoriales y asociaciones público-privadas. Elementos para su análisis desde la perspectiva de gestión pública. Bogotá: Escuela Superior de Administración Pública. 
Conato, D. \& Rhi-Sausi, J. (2008) Cooperación Descentralizada Unión Europea - América Latina y desarrollo económico local. Colección de Estudios de Investigación Número 6. Recuperado de: http://www.cespi.it/PDF/coop-desc-rhisausi-conato.pdf

Congreso de la Republica de Colombia. (2011). Proyecto de Ley Orgánica de Ordenamiento Territorial - Proyecto de Ley por el cual se dictan normas orgánicas de ordenamiento territorial.

Cuervo, L. M. \& González, J. (1997). Industria y ciudades en la era de la mundialización. Un enfoque socio espacial. Bogotá: TM editores.

DANE - Departamento Administrativo Nacional de Estadística. (2005). Censo General 2005, perfil Boyacá. Recuperado de: http://www.dane.gov.co/files/censo2005/PERFIL_PDF_ CG2005/15000T7T000.PDF

DANE - Departamento Administrativo Nacional de Estadística. (2011). Encuesta Anual Manufacturera. Recuperado de http://www.dane.gov.co/index.php/construccion-enindustria/industria/encuesta-anual-manufacturera-eam

DNP - Departamento Nacional de Planeación. (2013). Taller de Identificación de Proyectos de Alto Impacto Regional.

Fals-Borda, O. (1957). El hombre y la tierra en Boyacá. Bogotá: Punta de Lanza.

Fals-Borda, O. (1996). Región e Historia. Elementos sobre Ordenamiento y Equilibrio Regional en Colombia. Bogotá: Tercer Mundo.

Ferrari W. (2003). La necesidad de optimizar la cooperación internacional: algunas experiencias latinoamericanas. Ponencia presentada en el VIII Congreso Internacional del CLAD sobre la Reforma del Estado y de la Administración Pública, Panamá.

Guaqueta, A. (1995). La cooperación técnica en Colombia como una herramienta estratégica de política exterior. Colombia Internacional, (30), 3-15.

Gutiérrez, J. (2011). Cooperación internacional descentralizada (CID) para la gestión de proyectos territoriales. Entramado, 7(1), 50-71.

Instituto de Ciencia Política-ICP. (2011). Perspectivas de la descentralización y la autonomía territorial Ley Orgánica de Ordenamiento territorial LOOT. Boletín Debate de Coyuntura Legislativa, 6, 1-4. Recuperado de: http://icpold.icpcolombia.org/archivos/observatorio/ boletin_193

Niño-Amezquita, J. L. (2010). Le pouvoir local et la decentralisation, un processus inachevé: Le cas de la Colombie. École des Hautes Etudes Internationales Master Thesis. París.

Mendoza, A. (1992). Teoría y Sinopsis de la Constitución de 1991. Bogotá: Doctrina y Ley. 
Ocampo, J. (2006). Boyacá en la revolución de la independencia. Bogotá: Búhos editores.

Olaya, S. and Vélez, J. (2009). La cooperación descentralizada en Colombia. Anuario OCD. Montevideo: OCD

Pécaut, D. (2012). Orden y Violencia, Colombia 1930-1953. Medellín: EAFIT.

Planas, P. (1997). Regímenes políticos contemporáneos. Lima: FCE.

PNUD. (2005). Informe Departamental del Índice de Desarrollo Humano Boyacá. Recuperado de: http://www.pnud.org.co/img_upload/36353463616361636163616361636163/Boyaca_ final.pdf

Riffo, L. (2013). 50 años del ILPES: evolución de los marcos conceptuales sobre desarrollo territorial. ILPES-CEPAL.

Rhi-Sausi, J.L. (2008). La cooperación transfronteriza en América Latina. Curso de verano, Universidad Complutense de Madrid.

Velandia, R. (1971). Historia Geopolítica de Cundinamarca. Bogotá: Lotería de Cundinamarca. 
Recepción: 3 de febrero de 2015

Evaluación:24 de marzo de 2015

Aprobación: 2 de mayo de 2015 